\title{
Jornais e jornalistas em perspectiva histórica
}

DOI: https://doi.org/10.1590/1809-58442020214

\author{
Jefferson José Queler ${ }^{1}$ \\ http://orcid.org/0000-0002-4252-6620
}

${ }^{1}$ (Universidade Federal de Ouro Preto, Instituto de Ciências Humanas e Sociais, Departamento de História. Mariana - MG, Brasil).

ABREU, A. A. Desafios da notícia: o jornalismo brasileiro ontem e hoje. Rio de Janeiro: FGV Editora, 2017. 228p.

Em "Desafios da notícia: o jornalismo brasileiro ontem e hoje" (2017), Alzira Alves de Abreu traz nova e estimulante contribuição para o estudo da imprensa e do jornalismo brasileiros desde a década de 1950 até os dias atuais. Esta obra reúne uma série de estudos que lidam com assuntos como processos de modernização dos jornais, transformações nas condições de trabalho e nas visões de mundo de jornalistas, censura durante a ditadura civil-militar, novas tendências jornalísticas a partir do processo de redemocratização, métodos de jornalistas para conseguir e apurar suas fontes, e jornalismo eletrônico. Trata-se de obra bastante abrangente, escrita em linguagem clara e objetiva, capaz de fornecer subsídios aos interessados em compreender melhor as condições de produção de notícias no cenário brasileiro em perspectiva histórica.

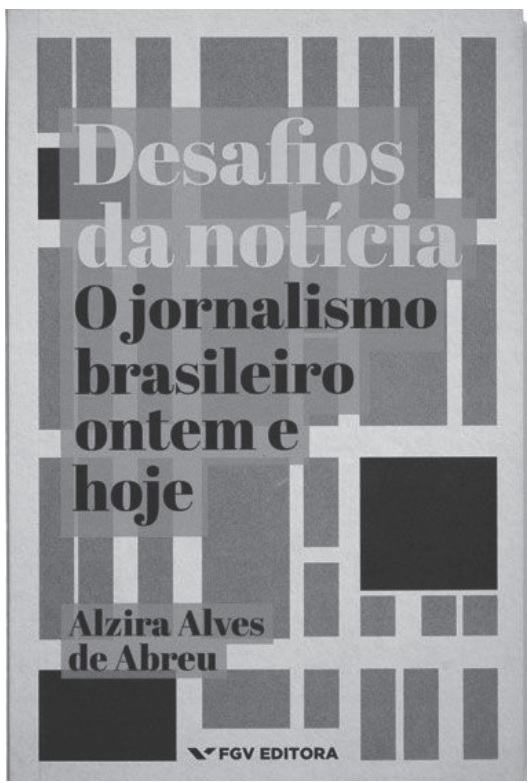

Alzira Abreu tem doutorado em Sociologia e é pesquisadora associada do Centro de Pesquisa e Documentação de História Contemporânea do Brasil (CPDOC). Possui ampla experiência no estudo das elites políticas republicanas e da imprensa e do jornalismo. Autora de diversos livros, poderíamos destacar entre eles "A imprensa em transição: $o$ jornalismo nos anos 50” (ABREU; LATTMAN-WELTMAN; MORAES; ABREU, 1996) e "A modernização da imprensa" (1970-2000) (ABREU, 2002). Além disso, publicou "Eles mudaram a imprensa” (ABREU; LATTMAN-WELTMAN; ROCHA, 2003), com Fernando Lattman-Weltman e Dora Rocha, e “Elas ocuparam as redações” (ABREU; ROCHA, 2006), com Dora Rocha. No livro ora analisado, a autora reúne textos discutidos em congressos e publicados em anais, entre 1996 e 2016. É uma obra heterogênea, cujas partes foram produzidas para públicos distintos e em diferentes conjunturas. Ao mesmo tempo, porém, 
conserva um fio condutor ao abordar transformações na imprensa em geral no decorrer das últimas décadas.

Os artigos reunidos no livro seguem caminhos abertos por estudos produzidos sobre os jornais no final da década de 1970. Até então, estes últimos eram amplamente compreendidos como Aparelhos Ideológicos de Estado - na acepção do estruturalismo, portadores de ideologias da classe dominante e responsáveis pela eliminação da ação autônoma dos indivíduos das camadas populares. Tal perspectiva afastava muitos sociólogos e historiadores dos jornais. Uma mudança de atitude destes últimos diante da imprensa escrita se deve, sobretudo, a apropriações da teoria gramsciana relacionada aos jornais. Em abordagens inspiradas por essa corrente, estudos dos periódicos passaram a ser considerados importantes por lançarem luzes sobre o processo de produção de hegemonia pela classe dominante. Alzira Abreu incorpora, então, a ideia de que os jornais e os jornalistas podem ser tomados como fonte privilegiada de análise e atualiza essa discussão, ao empregar pressupostos de historiadores que, nas últimas décadas, passaram a revalorizar os acontecimentos e os fatos, concebendoos como o cerne de suas análises.

A questão da modernização da imprensa é um eixo que perpassa vários capítulos do livro. Um marco importante é delineado na década de 1950, quando o padrão de jornalismo norte-americano aos poucos começa a se tornar dominante entre os grandes jornais no Brasil. O jornalismo literário, predominante até aquele momento, passa a ceder espaço a um jornalismo que se apresenta como neutro, imparcial, objetivo. Nos anos subsequentes, durante a ditadura civil-militar, muitos jornalistas fizeram um contraponto a essa tendência ao ligarem-se a causas políticas. O perfil do jornalista, naquele momento, era o do intelectual engajado e romântico, normalmente associado a utopias voltadas para a criação de um mundo mais justo.

A divulgação do cenário econômico era de amplo interesse dos governos militares, que procuravam se legitimar pelo crescimento, tanto mais pelo fato de que esse tipo de noticiário se baseava em dados oficiais. A despeito disso, numerosos jornalistas conseguiram veicular críticas ao regime, de maneira direta ou indireta, seja pela veiculação de análises de economistas estrangeiros criticando a desigualdade social ou pela cobertura de movimentos grevistas como aqueles ocorridos no fim da década de 1970 no ABC. Alzira Abreu, por meio de uma série de entrevistas com profissionais da imprensa, demonstra como as visões de mundo de jornalistas vêm se alterando profundamente ao longo das últimas décadas. Os novos repórteres procuram assumir uma postura tida por eles como neutra, imparcial, objetiva, similar à do expert em economia. A autora apresenta essas mudanças de maneira independente das transformações de décadas anteriores. Contudo, seria o caso de indagar até que ponto o processo de modernização da imprensa encetado na década de 1950 possui continuidades, ou descontinuidades, com as transformações no ethos dos jornalistas no presente, os quais parecem ter internalizado, em larga medida, os pressupostos de uma visão tecnicista encampada por corrente influente do jornalismo norte-americano. 
Durante o processo de redemocratização e em anos posteriores, o jornalismo de matriz norte-americana continuaria a ser apropriado por jornais brasileiros. Em tal conjuntura, tornase cada vez mais comum o “jornalismo cidadão”, em que periódicos dedicam grande parte de seu espaço para a veiculação de queixas de consumidores. Essa orientação, ao mesmo tempo que faz avançar a eficiência de órgãos de defesa do consumidor, coloca o jornalista em situação contraditória à ética de seu ofício, alinhando-o a interesses de determinados indivíduos. Outra vertente do jornalismo dos Estados Unidos é o chamado “denuncismo”. Na ânsia pela conquista de leitores, jornais e revistas buscam escândalos de personalidades públicas para turbinar suas vendas. Por vezes, fazem um trabalho apressado, sem averiguação aprofundada de fontes, e assim submetem indivíduos sem culpa a julgamentos injustos da parte dos leitores; em outras, trazem à luz casos de corrupção que de outra maneira ficariam longe dos olhos do público.

Alzira Abreu chama a atenção para as duas potencialidades desse fenômeno. Por um lado, pode contribuir para a cidadania informando os sujeitos acerca das zonas pouco visíveis do poder político. Por outro, pode levar à desconfiança generalizada da população no que diz respeito às suas elites políticas. A autora não chega a definir para qual lado a balança tem pendido nestes últimos tempos, o que poderia ser tema para uma possível pesquisa.

\section{Referências}

ABREU, A. A.; LATTMAN-WELMAN, F.; MORAES, M.; ABREU, P. A imprensa em transição: o jornalismo nos anos 50. Rio de Janeiro: FGV Editora, 1996.

ABREU, A. A.; LATTMAN-WELTMAN, F.; ROCHA, D. Eles mudaram a imprensa. Rio de Janeiro: FGV EDITORA, 2003.

ABREU, A. A. A modernização da imprensa (1970-2000). Rio de Janeiro: Jorge Zahar Editora, 2002.

ABREU, A. A. Desafios da notícia: o jornalismo brasileiro ontem e hoje. Rio de Janeiro: FGV Editora, 2017.

ABREU, A.A.; ROCHA, D. Elas ocuparam as redações. Rio de Janeiro: FGV Editora, 2006.

\section{Jefferson José Queler}

Graduado em História pelo Departamento de História da Faculdade de Filosofia, Letras e Ciências Humanas da Universidade de São Paulo (USP). Mestre e Doutor em História pela Universidade Estadual de Campinas (Unicamp). Possui estágios pós-doutorais pela Universidade Estadual de Campinas e Universidade de Birmingham - Reino Unido. Professor Associado do Departamento de História da Universidade Federal de Ouro Preto (UFOP). E-mail: jeffqueler@hotmail.com.

Recebido em: 22.11.2019

Aprovado em: 17.06.2020

Este artigo é publicado em acesso aberto (Open Access) sob a licença Creative Commons Attribution Non-Commercial (CC-BY-NC), que permite uso, distribuição e reprodução em qualquer meio, sem restrições, desde que sem fins comerciais e que o trabalho original seja corretamente citado.

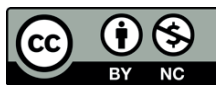

